\title{
Study of Potential Impacts of Using Sewage Sludge in the Amendment of Desert Reclaimed Soil on Wheat and Jews Mallow Plants
}

\author{
Ahmed Mazen, Fayza A. Faheed* and Atef F. Ahmed \\ Botany Department; Faculty of Science; Sohag; 82524; Sohag - Egypt
}

\begin{abstract}
This investigation was conducted to study the impacts of using sewage sludge at different concentrations (0, 10, 25, $50,75 \%)$ in amendment of desert reclaimed soil properties and some physiological aspects in wheat and jews mallow plants. Generally adding sewage sludge to desert soil improved the soil texture, raised the organic matter contents, water holding capacity and lowered $\mathrm{pH}$ value. The contents of NPK gradually increased as the ratio of sewage sludge increased. The fresh and dry weights and biosyntheses of pigment contents of the variously treated test plants were increased by increasing the sewage sludge levels in the soil. Also, total carbohydrate and protein contents of sewage sludge-treated test plants were positively affected. With respect to the proline content and total free amino acids, in most cases, it decreased significantly, expect at 75\% sewage sludge, which was higher than that of other concentrations. Also, the accumulation of metal was generally higher, especially in the root than that in the shoot system in the test plant tissues.
\end{abstract}

Key words: Heavy metals, protein, proline, free amino acids

\section{INTRODUCTION}

Over the past few decades, urban water supplies have improved considerably in developing countries and which has also increased the problem of waste water disposal. Reuse of effluent and sludge, resulting from the sewage treatment, in agriculture seems attractive as it offers a solution of other problems beside the problem of disposal, such as the scarcity of conventional water resources and the poor physical and chemical properties of soil. Use of sewage sludge in manuring the newly reclaimed desert lands is expected to be of special benefit because of the soil improving effect on physical and chemical properties of the sludge. Also, sewage sludge primary constituents, e.g., organic matter, phosphorus and nitrogen are agronomically beneficial to the crop growth. The addition of sludge to the soil generally promotes plant growth more than the commercial fertilizer. Christodoulos and Margarita (1996) showed that plant height increased in maize individuals by $77 \%$ in the sludge amended treatment compared to $25 \%$ in the case of the commercial fertilizer.

As previously mentioned, one of the most important concerns of using sewage sludge in agriculture is the uptake of toxic metals by the plants and hence, entrance to food chain and eventually, exposure of human health to danger

*Author for correspondence: fayzafaheede@yahoo.com 
due to stepwise concentration of these metals as they proceed through food chain stages. Metals such as $\mathrm{Pb}$ and $\mathrm{Cd}$ are known to be cumulative toxins that can affect the warm blooded animals and mammals (zootoxicity). Concentrations of $\mathrm{Pb}$ and $\mathrm{Cd}$ were found to be higher in the liver and kidneys of the animals (Birley and Lock 2001) exposed to the pollutants than those that were not. Dietary intake of heavy metal-contaminated crop plants affect human health in the long term by damaging the nervous, pulmonary and renal systems (Aoshima et al., 2003).

The objective of this work was to study the potential impacts of using sewage sludge in manuring newly reclaimed desert lands on the physical and chemical properties of soil. Another important objective of this study was to explore the potential hazards of contamination of reclaimed soil by heavy metal concentrated in sewage sludge and it's probable negative consequences on the crop productivity and general human health.

\section{MATERIALS AND METHODS}

\section{Plant material}

Two plant species, namely, wheat (Triticum vulgare cv. Giza 168) and jews mallow (Corchorus olitorius) were chosen in this study.

\section{Treatment of plants by growth on sewage sludge amended-soil}

Air-dried sewage sludge was collected from the sewage treatment station of El-deer, Sohag city. In this station, sewage sludge resulting from the sewage treatment is disposed in drying beds and left to dry under the sun. The sewage sludge was collected randomly from dry material from all the drying basins, was further air-dried, crushed to pass a $2 \mathrm{~mm}$ sieve, and kept for preparation of culture mixture, the dry sludge was mixed with sand soil to have five sludgesoil mixtures with sludge representing $0,10,25$, 50 , and $75 \%$ of the mixtures. The soil mixture with ratio $0 \%$ served as the control treatment. Ten grains of wheat or twenty seeds of jews mallow were germinated on the soil-sludge mixtures in plastic pots $(25 \mathrm{~cm}$ in diameter and $30 \mathrm{~cm}$ in depth). Each pot contained two kilograms of the mixture. During the germination and growth, plants were watered with tap water every other day. Whenever needed, all the pots received equal volume of water. Plants were supplied with a half strength Hoagland nutrient solution (Hoagland and Arnon 1950) every alternate week. After eight weeks, all wheat and jews mallow plant material were sampled for analysis. All jews mallow plants were cut while, in case of wheat experiments three plants were left to continue the growth till seed setting.

\section{Analysis of soil (desert and sludge soil) Physical analysis}

For mechanical analysis of soil, the pipette method described by Richards (1954) was followed. Water holding capacity was determined using the standard methods outlined by Dewis and Freiteas (1970).

\section{Chemical analysis}

Organic matter (OM) was determined following the method of Jackson (1967). Soil reaction was in a 1: 2.5 soil-water suspension using a $\mathrm{pH}$ meter (Jackson 1967). Total soluble salts were determined in a 1: 2.5 soil-water extract by measuring the electrical conductivity (EC) of the solution (Jackson 1958). Available potassium was extracted using 1 mole neutral $\mathrm{CH}_{3} \mathrm{COONH} 4$ and measured with Atomic Absorption Spectrophotometr (Perkin-Elemer 3300). Total nitrogen content of the sewage sludge was determined after digestion with $\mathrm{H}_{2} \mathrm{SO}_{4}$-HCLO4 mixture (Jackson 1967). Available phosphorus was extracted with $\mathrm{NaHCO}_{3}$ and measured as described by Olsen and Sommers (1982). The heavy metals (Cd, $\mathrm{Pb}, \mathrm{Cu}$ and $\mathrm{Zn}$ ) were extracted with DTPA (diethylene triamine penta acetic acid) and measured with Atomic Absorption Spectrophotometr (Perkin-Elemer 3300) using the methods of Lindsay and Norvell (1978).

\section{Analysis of the plant materials}

At the end of the experimental period, samples subjected to the mixtures of sand soil and sludge (three replicates) were rapidly washed in the tap water and dried in an air- oven at $70^{\circ} \mathrm{C}$ to determine fresh and dry weights as well as to carry out the chemical analysis. The photosynthetic pigments (chlorophyll a, chlorophyll $\mathrm{b}$ and carotenoids) of the plants were determined using the spectrophotometeric method recommended by Metzner et al., (1965). Watersoluble sugars were determined using a known 
weight of the powdered tissue which was hydrolyzed in the distilled water for two hours in a boiling water bath. After cooling, the hydrolyte was filtered and filtrate was made up to a known volume,in which the water-soluble saccharides were determined by the anthrone sulphuric acid method (Fales 1951). To estimate the soluble proteins, powdered tissue samples were boiled in distilled water for two hours. After cooling, the extract was centrifuged and supernatant was decanted and made up to known volume with distilled water. The insoluble protein residue remaining after the extraction of the water-soluble fraction was treated with $\mathrm{NaOH}$. The plant protein content was determined according to Lowry et al. (1951), using bovine serum albumin as standard. Proline was extracted according to the method of Bates et al. (1973). Free amino acids were extracted from the plant tissues and determined according to the method of Moore and Stein (1948). A known weight of dry matter samples $(0.5 \mathrm{~g})$ was prepared for Atomic Absorption flame Spectrophotometer (Perkin-Elmer 3300).

$\mathrm{Cd}, \mathrm{Pb}, \mathrm{Cu}$ and $\mathrm{Zn}$ were determined for all the plants material (shoot and root of jews mallow and grain of wheat) using the methods of Lindsay and Norvell (1978).

\section{Data analysis}

Data presented are means T- standard deviation for three replicates.

\section{RESULTS AND DISCUSSION}

\section{Soil analysis}

\section{Soil physical and chemical properties}

Results of this study, generally, indicated improvement in desert soil texture due to the addition of sewage sludge (Table 1). The used desert loamy sand soil changed gradually to loamy with continuous addition of the sewage sludge. Loamy soil has lower ratio of sand and higher ratio of silt and clay than that of loamy sand. The water holding capacity (Table 2) of soil with $75 \%$ sewage sludge was 3-4 times higher than that of untreated soil. The general properties namely, $\mathrm{pH}$, electrical conductivity (EC) and organic matter $(\mathrm{OM})$ of the sewage sludge, desert soil, and their mixtures used are presented in Table 3. In general, adding sewage sludge to the desert soil increased the organic matter contents and lowered $\mathrm{pH}$ value in the resulting mixtures. The values of organic matter and $\mathrm{pH}$ in these mixtures depended on sewage sludge ratio in the mixture and the highest EC value was attained in soil mixture with $75 \%$ sewage sludge $(1.14 \mathrm{mmho} / \mathrm{cm})$. Sewage sludge used in this study compared to desert soil was found to have higher levels of $\mathrm{N}, \mathrm{P}$, and $\mathrm{K}$ than in the desert soil (Table 3). The contents of these elements in sewage sludge were greater than those in desert soil by 60,300 , and $50 \%$ respectively. The analysis for heavy metal content in sandy soil and sewage sludge revealed that all the tested heavy metals were several times higher in pure sludge compared to pure sandy soil (Table 3). .In pure sludge, for example, $\mathrm{Cd}$ was four times, $\mathrm{Cu}$ was 1.8 times, $\mathrm{Pb}$ was 2.1 times and $\mathrm{Zn}$ was around 1.4 times higher than their counterparts in sandy soil. The soil content of DTPA-extractable $\mathrm{Cd}, \mathrm{Cu}$, and $\mathrm{Pb}$ increased as the sludge application rates increased. The values of DTPA-extractable metals $(\mathrm{Cd}, \mathrm{Cu}, \mathrm{Pb}$, and $\mathrm{Zn})$ at the highest application rate $(75 \%)$ compared with the control soil were 3.4 fold for $\mathrm{Cd}, 1.86$ fold for $\mathrm{Pb}, 1.6$ fold for $\mathrm{Cu}$ and 1.3 fold for $\mathrm{Zn}$.

The physical and chemical properties of soil (Tables 1-3) showed the effect of adding sewage sludge to the desert soil. The water holding capacity of the employed desert soil clearly increased due to its amendment by sewage sludge. Sandy soil with many "large" particles drains well and is rather dry, whereas smaller particles like clay and silt do not drain well and retain water longer. Many papers have been published on the beneficial effects of sewage sludge amendment on crop yield and some physical and chemical properties of soil , such as improved soil structure, increased soil moisture and porosity, provision of plant nutrients, increased humus content and cation exchange capacity (Barzegar et al., 2002; Speir et al., 2003). The incorporation of organic materials, such as sewage sludge, into soil also promotes its biological activity (Saviozzi et al., 1999). In this study, the chemical analysis of sewage sludge showed that the $\mathrm{pH}$ was neutral (7.1). High organic matter content $(15.4 \%)$ helped in improving the physical and chemical properties of sandy desert soil (Veeresh et al., 2003; GarciaGil et al., 2004). Hence, the lowness observed in $\mathrm{pH}$ values could be a result of both; dissolution of $\mathrm{CaCO}_{3}$ and the effect of organic acids of sewage sludge. In this study, the highest EC value was attained in soil mixture with $75 \%$ sewage sludge and it was $1.14 \mathrm{mmho} / \mathrm{cm}$. Also, sewage sludge used in this study compared to desert soil was 
found to have higher levels of $\mathrm{N}, \mathrm{P}$, and $\mathrm{K}$ than in desert soil, hence, the contents of these elements gradually increased as the ratio of sewage sludge increased in sewage sludge desert soil mixtures. The main problems of an excessive application of sewage sludge are plant toxicity due to the accumulation of heavy metals in soils (McGrath et al., 2000) but also the increase in its salt content (Hao and Chang, 2003). Sewage sludge metal contents could be arranged in the following order according to their contents; $\mathrm{Zn}>\mathrm{Cu}>\mathrm{Pb}>\mathrm{Cd}$. Comparing with metal contents of other municipal sewage sludge compost of different countries in Europe (Cottenie et al., 1982), the content of sewage sludge of El-deer station, located five kilometres west of Sohag city was still within the normal range or lower. Chaney and Ryan (1993) considered that sludge containing > $2000 \mathrm{ppm} \mathrm{Zn,} \mathrm{>} 800 \mathrm{ppm} \mathrm{Cu}$, and $0.5 \% \mathrm{Cd} / \mathrm{Zn}$ should not be applied to agricultural land. The sludge used in this study contained very lower amounts than the give toxic levels. This showed that the metal equivalent was much lower than the critical value. The USEPA (1993) proposed criteria for sewage sludge application, and consequenclly the levels used in this study were below the critical limits and therefore there were no hazard due to use of this sludge. Tietijen (1975) gave the following values of the tolerable contents of heavy metals in the soil; $100 \mathrm{ppm}$ for $\mathrm{Pb}$ or $\mathrm{Ni}$, and $5 \mathrm{ppm}$ for $\mathrm{Cd}$. Comparing these values with the present results (Table 3) it was found that at the highest application rate $(75 \%)$ of sewage sludge to sandy soil, the metal values were lower than the suggested tolerable levels. The possible combinations of soil types and plant species are very large, thus the variety of both plants and soils must be considered for the optimum use of sewage sludge as a fertilizer (Schmidt, 1997). For example, some studies indicated that sewage sludge application could be useful for cereal crops grown in different soils (Christie et al., 2001; Barzegar et al., 2002).

Table 1 - Effect of addition of various ratios of sewage sludge to desert soil on some physical properties of that soil (particle size distribution and texture grades of the studied soils).

\begin{tabular}{|c|c|c|c|c|c|}
\hline Soil composition & Coarse sand & Fine sand & Silt & Clay & Texture \\
\hline Desert soil $^{(1)}$ & 36.7 & 43.5 & 11.9 & 4.9 & Loamy sand \\
\hline $10 \% \mathrm{SS}^{(2)}$ & 34.7 & 41.4 & 12.7 & 6.3 & Loamy sand \\
\hline $25 \% \mathrm{SS}$ & 31.5 & 38.3 & 14.1 & 8.4 & Sandy loam \\
\hline $50 \% \mathrm{SS}$ & 26.8 & 33.2 & 16.1 & 11.8 & Sandy loam \\
\hline $75 \% \mathrm{SS}$ & 21.8 & 28.1 & 18.1 & 15.4 & Loam \\
\hline $100 \% \mathrm{SS}$ & 16.9 & 22.9 & 20.2 & 18.7 & Loam \\
\hline
\end{tabular}

(1) Control treatment (0\% SS); ${ }^{(2)} \mathrm{SS}-$ Sewage sludge.

Table 2 - Effect of addition of various ratios of sewage sludge to desert soil on water holding capacity content of that soil. Each value is the means of three replicates \pm Standard Deviation (SD) of three replicates.

\begin{tabular}{lccc}
\hline Treatment & $\mathbf{1}^{\text {st }}$ day & $\mathbf{3}^{\text {rd }}$ day & $\mathbf{5}^{\text {th }}$ day \\
\hline Desert soil ${ }^{(1)}$ & $16.327 \pm 0.760$ & $14.133 \pm 0.439$ & $11.167 \pm 0.907$ \\
$10 \%$ SS ${ }^{(2)}$ & $25.277 \pm 1.662$ & $21.987 \pm 1.053$ & $19.597 \pm 1.426$ \\
$25 \%$ SS & $33.523 \pm 4.503$ & $30.360 \pm 1.566$ & $27.230 \pm 0.661$ \\
$50 \%$ SS & $42.247 \pm 2.323$ & $35.720 \pm 1.882$ & $31.833 \pm 0.470$ \\
$75 \%$ SS & $51.827 \pm 1.850$ & $45.433 \pm 2.645$ & $40.367 \pm 2.161$ \\
\hline
\end{tabular}

(1)0\% SS; ${ }^{(2)} \mathrm{SS}$ - Sewage sludge. 
Table 3 - Effect of addition of various ratios of sewage sludge to desert soil on some chemical properties of that soil.

\begin{tabular}{|c|c|c|c|c|c|c|c|c|c|c|c|c|}
\hline \multirow{2}{*}{$\begin{array}{l}\text { Soil } \\
\text { composition }\end{array}$} & \multicolumn{3}{|c|}{$\begin{array}{c}\text { General chemical } \\
\text { properties }\end{array}$} & \multicolumn{3}{|c|}{ Available NPK } & \multicolumn{6}{|c|}{ Heavy matels } \\
\hline & $\begin{array}{c}\text { OM } \\
\%\end{array}$ & $\begin{array}{c}\text { EC } \\
\text { mmho/cm }\end{array}$ & $\begin{array}{c}\mathbf{p H} \\
\left(\mathbf{H}_{2} \mathbf{O}\right)\end{array}$ & $\mathbf{N}$ & $\begin{array}{r}P \\
\mathrm{mg} \mathrm{l}\end{array}$ & $\mathbf{K}$ & Cd & $\mathbf{P b}$ & & $\mathbf{Z n}$ & $\mathrm{Fe}$ & Mn \\
\hline Desert soil & 0.2 & 0.61 & 7.9 & 53 & 3 & 77 & 0.5 & 7.0 & 11 & 32 & 40 & 23 \\
\hline $10 \% \mathrm{SS}$ & 1.7 & 0.68 & 7.8 & 56 & 4 & 80 & 0.6 & 8.0 & 12 & 34 & 43 & 24 \\
\hline $25 \% \mathrm{SS}$ & 3.9 & 0.79 & 7.7 & 60 & 5 & 85 & 0.8 & 9.0 & 14 & 36 & 46 & 26 \\
\hline $50 \% \mathrm{SS}$ & 7.7 & 0.97 & 7.5 & 69 & 7 & 93 & 1.2 & 11.0 & 16 & 39 & 52 & 30 \\
\hline $75 \% \mathrm{SS}$ & 11.4 & 1.14 & 7.3 & 77 & 9 & 102 & 1.7 & 13.0 & 18 & 42 & 57 & 33 \\
\hline
\end{tabular}

\section{Plant tissue analysis}

Growth represented in fresh and dry weights Results of the effects of cultivation of the plants on desert soil amended with sewage sludge on the growth of the plants are summarized in Figure 1. Both the plants showed significant effects as the ratio of sewage sludge increased in mixture until 50\% (Fig. 1a-d). Beyond this point, there was no obvious effect for further addition of sludge to soil mixture. This result was very clear in case of shoots of test plants compared to those of roots.

Previous studies have indicated that the application of sewage sludge produced varied growth responses in different plants with positive growth responses in order crops (Zasoski et al., 1983). According to Chaney et al, (1978), the crops may suffer yield reductions even when metal phytotoxicity is not visually indicated. In this study, the performance of the studied physiological parameters in the tested plants was generally improved or at least was unaffected. The physiological performance was reflected in enhancing the dry matter yield in these plants, which was almost identical to that seen in Zea mays, Corchorus, Eruca, Raphanus and Spinacia (Mazen, 1995 and 2003), or in Hordeum vulgare L. (Antolín et al., 2005). The higher yields in sludge treated crops are usually attributed to an improvement in the soil conditions, by the supply of additional carbon from the sludge (Christie et al., 2001).

\section{Photosynthetic pigment content}

The responses of tissue content of photosynthetic pigments fractions (chlorophyll $a$, chlorophyll $b$, carotenoids) in wheat and jews mallow growing on desert soils with sewage sludge are presented in Figure 2. The content of photosynthetic pigments were enhanced in response to the presence of sewage sludge. The enhancement in pigment content continued to slightly rise in parallel to raising the sludge content in soil up to $50 \%$, when the total pigment content of the leaves of wheat and jews mallow plants increased by 1.5 and 1.23fold compared with controls, respectively. After that no further effect was observed for higher sludge in soil.

No toxicity or deficiency symptoms were observed in sewage sludge amended plants but contrary to the expectations, the cultivation of test plants on sewage sludge amended desert soil generally showed higher chlorophyll content. This was almost identical to that seen in Corchorus, Daucus, Eruca, Lactuca, Raphanus and Spinacia (Mazen, 2003) and in Zea mays (Mazen, 1995).

\section{Tissue carbohydrate content}

Figure 3 shows the carbohydrate contents (soluble, insoluble, as well as total) of the shoots and roots of wheat and jews mallow plants treated and untreated with sewage sludge. The test plants grown under different concentrations of sewage sludge induced considerable variations in their carbohydrate contents. The variations depended on the sewage sludge level applied in the soil. The type and extent of effect of growing plants on sewage sludge-amended soil on carbohydrate metabolism depended on the plant species and the plant organ. In wheat plants, for example, content of both the fractions of carbohydrate in shoot system was meagerly reduced in response to growth on sewage sludge containing soil (Fig. 3a). These fractions however, were slightly enhanced in root system of this plant (Fig. 3b). In jews mallow, the levels of soluble and insoluble fractions of carbohydrate increased in the sludge- 
supplemented soil. The effect was weaker in root system compared to shoot system (Fig. 3cd).Bearing in mind that leaf total soluble sugars amounts depended primarily on photosynthesis, the percentage of sugar in Phyllanthus amarus plants decreased by Cd (Rai et al., 2005). This finding was also supported by Narwal and Singh
(1993). They have reported decreased concentration of reducing and non-reducing and total sugars as a result of heavy metal supply in different plant species. This could be attributed to reduced activity of net photosynthetic rates due to high metal concentration.

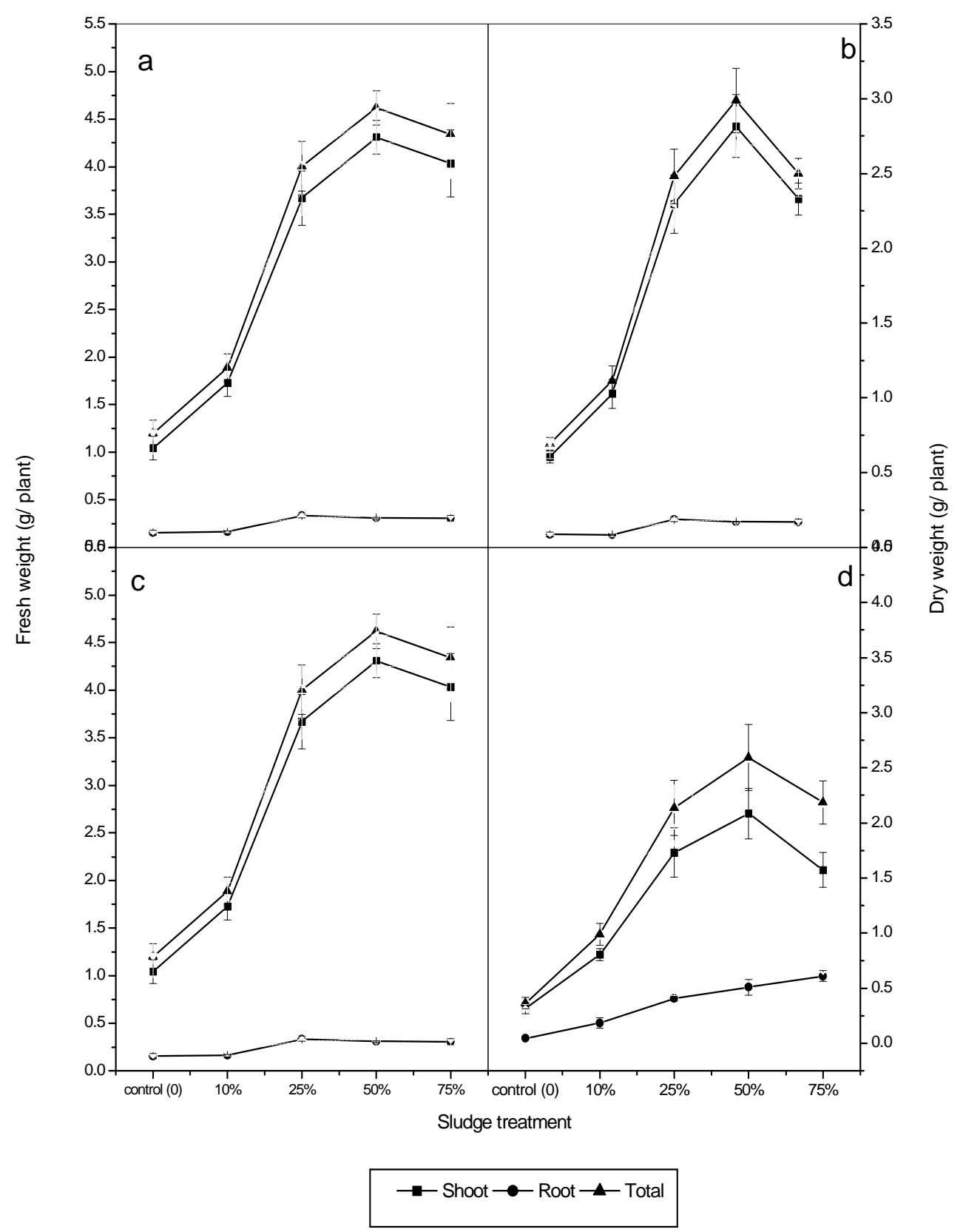

Figure 1- Effect of addition of various ratios of sewage sludge to desert soil on which wheat (a, b) and jews mallow (c, d) were growing on their growth of shoot, root as well as total weight of each single plant: Each data point is a mean of three replicates and error bar on each data point equal \pm Standard Deviation $(\mathrm{SD})$ from that mean. 


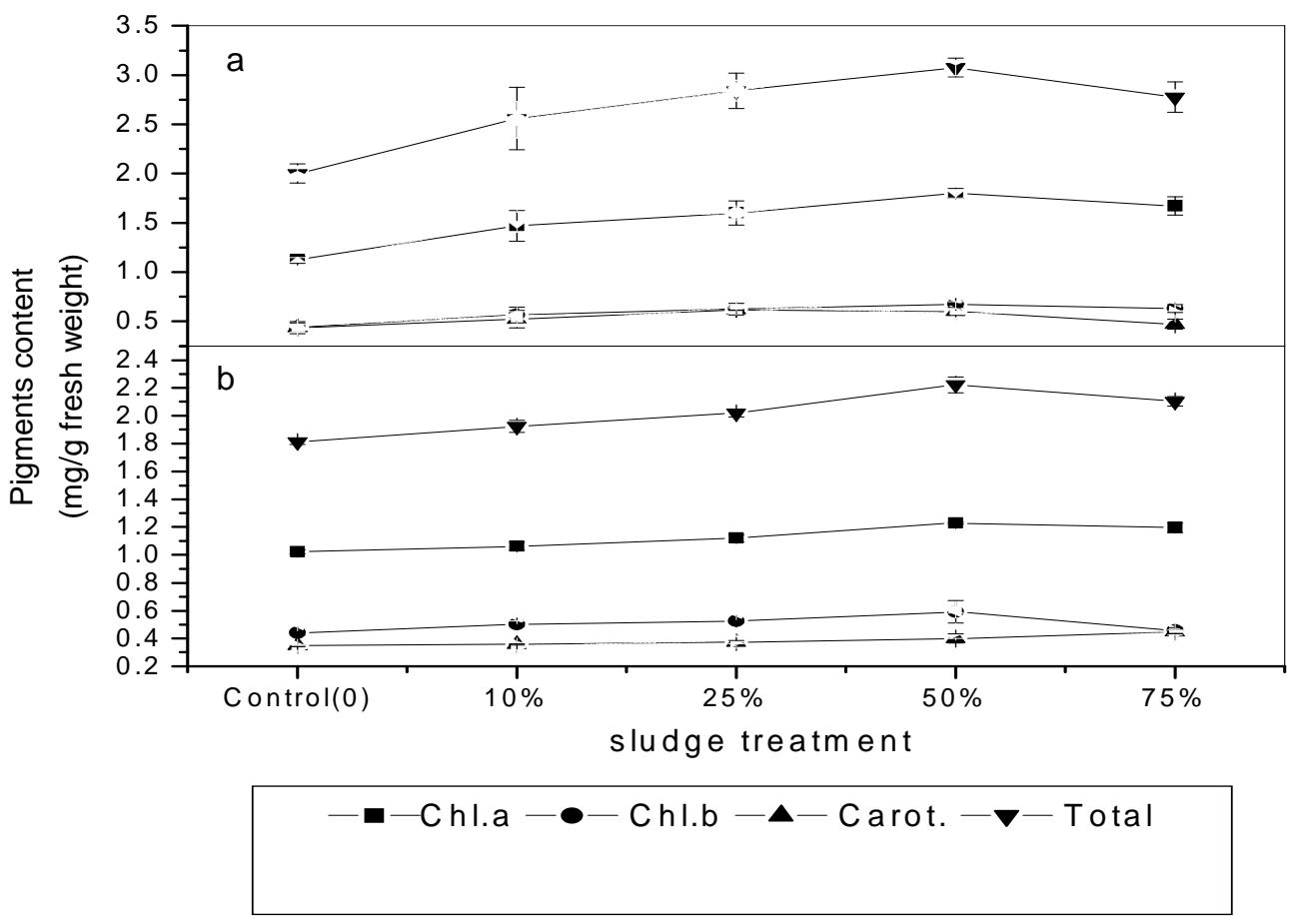

Figure 2 - Effect of addition of various ratios of sewage sludge to desert soil on which wheat and jews mallow were growing on their pigment content of: a) wheat plants; b) jews mallow plants. Each data point is a mean of three replicates and error bar on each data point equal \pm Standard Deviation $(\mathrm{SD})$ from the mean

\section{Tissue protein content}

In order to test the interactive effects of the application of sewage sludge to sandy soil on shoot and root protein content, resulted are shown in Figure 4. Sewage sludge-treated shoot of wheat plant revealed a significant increase in the soluble protein content, while insoluble one, more or less was unaffected in respect to the control. The total protein content of sewage sludge-treated shoot of wheat plant was positively affected (Fig. 4a). Also, the soluble and insoluble protein content of sewage sludge-treated wheat plant roots increased with increasing the sewage sludge concentrations (Fig. 4b). Sewage sludge-treated shoot of jews mallow plant revealed a significant increase in the soluble and insoluble protein contents, while insoluble protein, was less affected than the soluble one in respect to the controls. The total protein content of sewage sludge-treated shoot of jews mallow plant was positively affected (Fig. $4 c)$. The root insoluble protein content fractions (soluble, insoluble as well as total) in the roots of sewage sludge-treated jews mallow plant significantly increased with increasing sewage sludge concentrations (Fig. 4d). For example, root soluble protein content increased by 1.2-fold when treated with $75 \%$ sewage sludge compared with the control. But it was noteworthy that in both shoot and root, the total protein content at $75 \%$ sewage sludge was less than that of 50\% sewage sludge (Fig. 4d).

Protein synthesis is essential for normal cell proliferation, differentiation and growth. A variety of environmental factors have been reported to influence the synthesis of plant proteins (William, 1989). In support to sewage sludge results, Mazen (2003) reported that the cultivation of plants (Corchorus, Eruca, Raphanus, Daucus, Lactuca and Spinacia) on sewage sludge amended soil was generally enhanced the total soluble proteins. In Zea mays, total soluble proteins also increased (Mazen, 1995). This was expected, because the used sewage sludge was fresh and, hence, rich in nitrogen. 


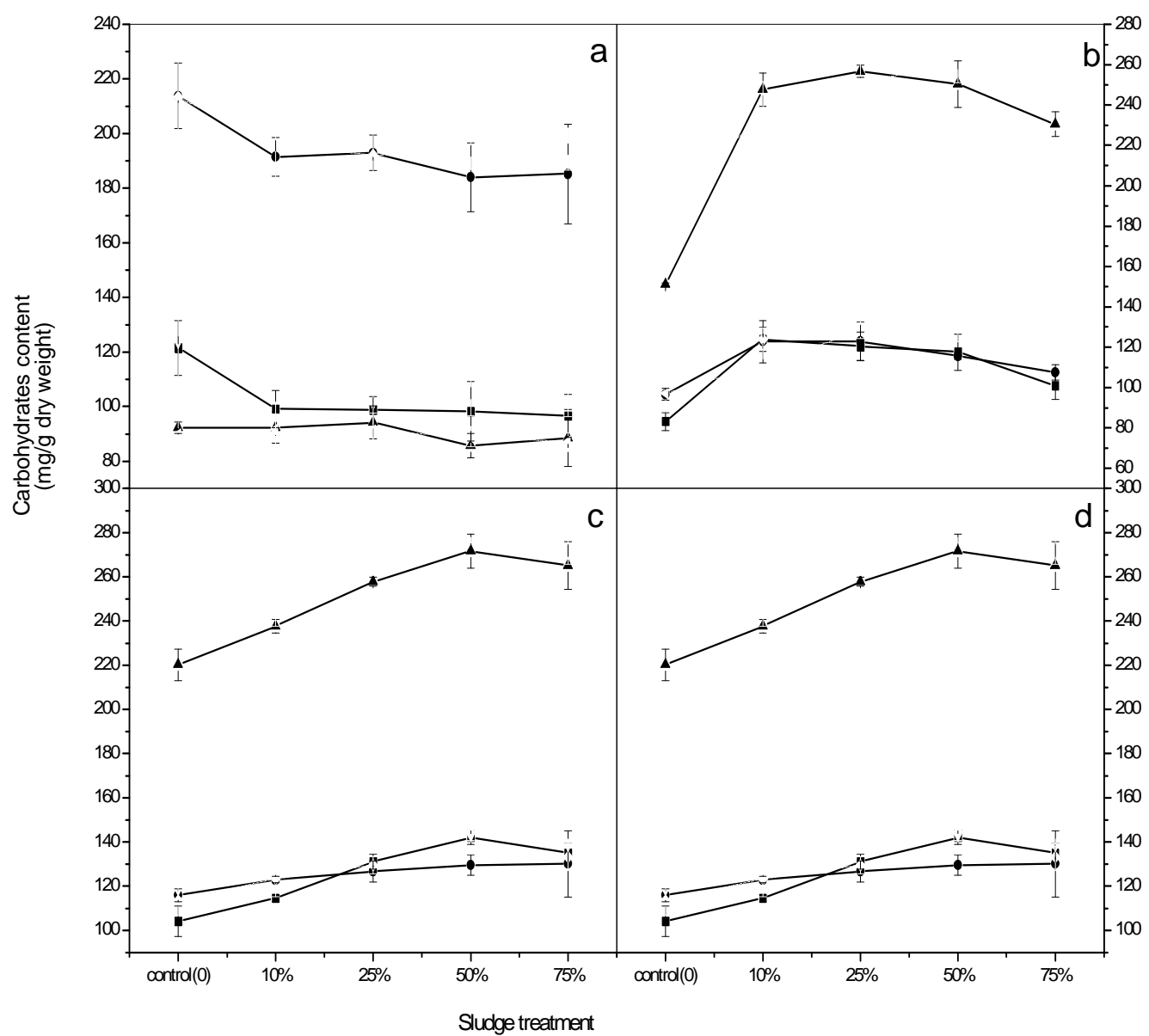

Figure 3 - Effect of addition of various ratios of sewage sludge to desert soil on which wheat and jews mallow were growing on their soluble, insoluble and total carbohydrate content of: a) shoot of wheat plants; b) root of wheat plants; c) shoot of jews mallow plants; d) root of jews mallow plants. Each data point is a mean of three replicates and error bar on each data point equal \pm Standard Deviation (SD) from that mean.

\section{Tissue content of amino acids}

\section{Total free amino acids}

The changes in the contents of free amino acids, other than proline were also followed in shoots and roots of wheat and jews mallow plants (Fig. 5). It was seen that in wheat plant, the contents of total free amino acids (including only traces of proline and hydroxyl proline) of shoots and roots decreased when treated with 10 and $25 \%$ sewage sludge in comparison with their controls. In respect to $50 \%$ sewage sludge, total free amino acids of shoot were less than their control, but in root, total free amino acids were the same as of their control. In contrast, total free amino acids of both shoot and root of wheat plant treated by $75 \%$ sewage sludge were higher than that of their controls (Fig. 5a-b). In jews mallow plant, the contents of total free amino acids in shoots and roots decreased when treated with 10, 25 and $50 \%$ sewage sludge in comparison with their controls. In the roots of jews mallow plant treated with 10 , 25 and $50 \%$ sewage sludge, the total free amino 
acids were the same values, but in the shoots, total free amino acids were less in the plant treated with $25 \%$ sewage sludge than that of 10 and $50 \%$ sewage sludge. In contrast, total free amino acids of shoot and root of jews mallow plant treated by $75 \%$ sewage sludge were higher than that of their controls (Fig. 5c-d).

Total free amino acids especially proline accumulate in plants, due to heavy metal stresses (Leskó et al., 2002; Siripornadulsil et al., 2002; Faheed 2005). Cd stress could lead to protein degradation via amino acid catabolism resulting from a general reduction ofplant development. In this aspect, osmotic adjustment may be associated with the increase in proline and polyamine contents of plant cells (Yancey et al., 1982). Proteins are hydrolyzed into a mixture of free amino acids and small peptides by a concerted action of proteases and peptidases (Ranki et al., 1990). However, on being subjected to environmental stresses altered behaviour of proteolytic enzymes and modulation in the level of proteins and free amino acids is observed (Shah and Dubey, 1998a).

\section{Proline content}

Proline content of sewage sludge treated and untreated shoot and root of wheat and jews mallow plants are shown in Figure 6. All the concentrations of sewage sludge caused significant decrease in proline content except at $75 \%$ which was higher than that of other concentrations (10, 25 and 50\%). One mechanism by which many plants and algae respond to detoxify the toxic heavy metals is the production of proline (Shah and Dubey, 1998b; Mehta and Gaur, 1999; Verma, 1999). The accumulation of proline in stressed plants is associated with the reduced damage to the membranes and proteins (Shah and Dubey, 1998b; Verma, 1999). Proline synthesis has been implicated in the alleviation of cytoplasmic acidosis and may maintain NADP/NADPH ratios at values compatible with metabolism (Hare and Cress, 1997). Rapid catabolism of proline upon relief of stress also may provide reducing equivalents that support mitochondrial oxidative phosphorylation and the generation of ATP for recovery from stress-induced damage (Hare and Cress, 1997). However, there has been much disagreement regarding the mechanism(s) by which proline reduces the heavy metal stress. Free proline has been proposed to act as an osmoprotectant (Taylor, 1996), a protein stabilizer (Shah and Dubey, 1998b), an inhibitor of lipid peroxidation (Mehta and Gaur, 1999), a hydroxyl radical scavenger (Smirnoff and Cumbes, 1989), and a singlet oxygen scavenger (Alia et al., 2001). It is evident that there is no clear consensus regarding the mechanism(s) by which proline reduces the heavy metal stress.

\section{Tissue heavy metal content}

Tables 4 and 5 show the metals content in the shoots, roots and grains of wheat plant in the shoots and roots of jews mallow plant respectively. In the test plants tissues, the concentrations of all metals increased with the increased ratio of sludge in soil mixtures, showing, the rate of sludge application strongly influenced the metal content of these plants. The accumulation of elements was generally higher in the root than in the shoot system, except for $\mathrm{Zn}$ treated wheat which was nearly equal in both. It is noteworthy that in wheat plant, $\mathrm{Cd}$ and $\mathrm{Cu}$ levels increased by 1.84 and 2.11 times in the shoots and by 8.15 and 3.03 times in the roots, respectively.

$\mathrm{Pb}$ and $\mathrm{Zn}$ levels increased by 1.15 and 1.19 times in the shoots and 1.37 and 1.13 times in the roots but only when treated by $75 \%$ sewage sludge. The accumulation magnitude of the elements in the grains (Table 4) was generally less than that in the shoots and roots of wheat plant. At $75 \%$ sewage sludge treated-wheat plant, the content of $\mathrm{Cd}$ and $\mathrm{Cu}$ increased by 3 . and 1.53 times in the grains, respectively, but $\mathrm{Pb}$ and $\mathrm{Zn}$ increased by 1.12 only in comparison with their controls. It was noteworthy that in jews mallow plant, $\mathrm{Cd}$ and $\mathrm{Cu}$ levels increased by 3.85 and 1.88 times in the shoots and by 3.64 and 1.91 times in the roots, respectively. Also, $\mathrm{Pb}$ and $\mathrm{Zn}$ levels increased by 1.18 and 1.19 times in the shoots, but by 1.23 and 1.1 times in the roots when treated by $75 \%$ sewage sludge.

It is deceptive to assess the application of sludge for crop production on the basis of physiological performance in a plant irrespective of the extent of the ability of this plant to accumulate the heavy metals. A plant may be able to accumulate high levels of toxic metals and its physiology may tolerate these levels and end up with a good yield. 


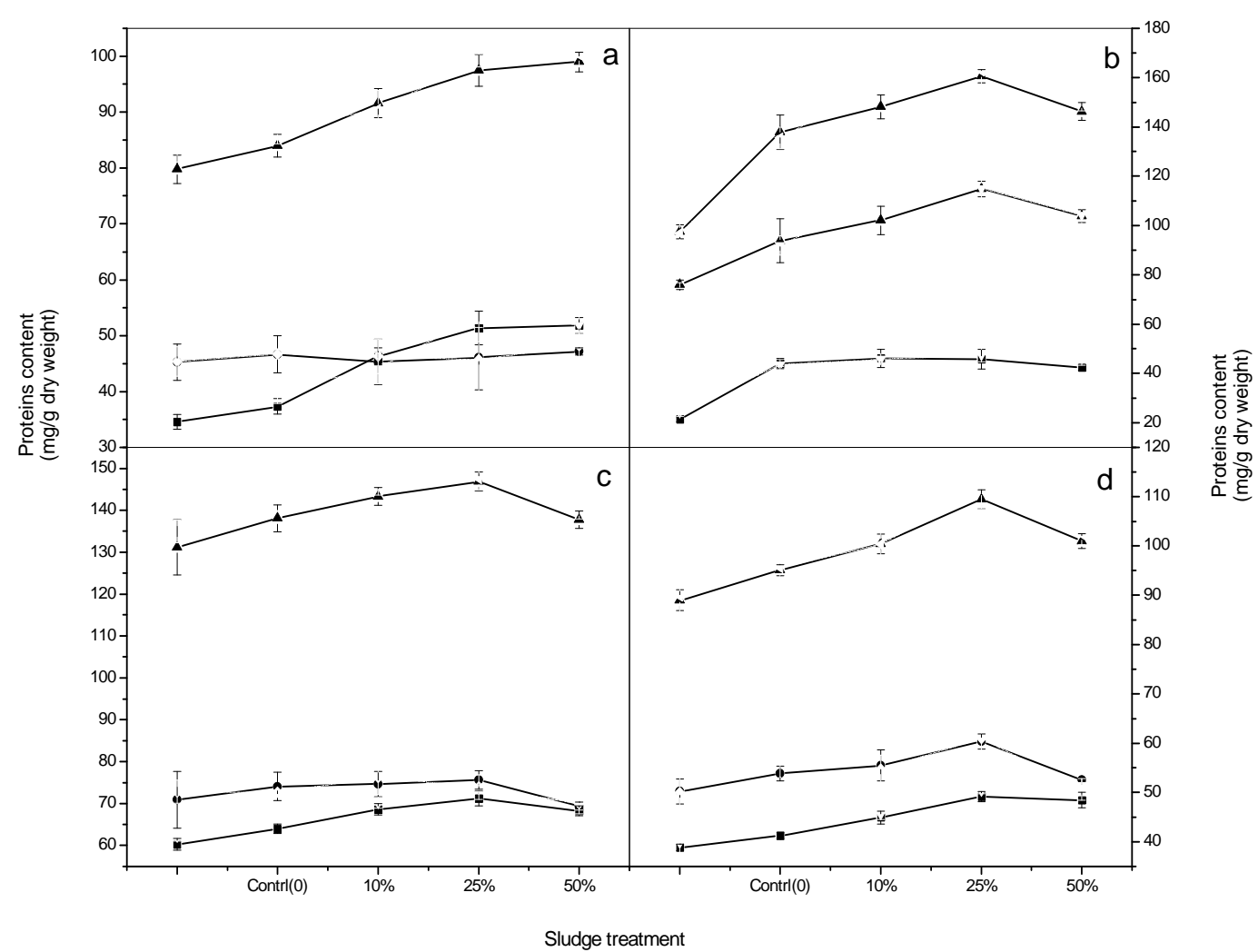

Sludge treatment

Figure 4 - Effect of addition of various ratios of sewage sludge to desert soil on which wheat and jews mallow were growing on their soluble, insoluble and total protein content of: a) shoot of wheat plants; b) root of wheat plants; c) shoot of jews mallow plants; d) root of jews mallow plants. Each data point is a mean of three replicates and error bar on each data point equal \pm Standard Deviation (SD) from that mean.

The uptake and concentration of heavy metals by the plants due to cultivation on sludge amended soils seems to be an inevitable process. Previous studies have reported the accumulation of toxic metals in different plants and tissues after their growth on sludge-amended soils (Heckman et al., 1987; Mazen, 1995). In the present study (Tables 4 and 5), the test plants tissues exhibited continuous increase in the concentrations of all metals as the ratio of sludge in soil mixtures increased, and the rate of sludge application strongly influenced the metal content of these plants. Sewage sludge has been used in forest lands (Davis, 1987), or/and it could be incorporated as an amendment to soil growing ornamental plantings. Other strategies could also be considered. One possible strategy is to alleviate rather than to totally prevent the effect. Of the factors that strongly influence the metal uptake from the soil is soil $\mathrm{pH}$ (Lester et al., 1983). Low soil $\mathrm{pH}$ increase metal ion uptake and according to Heckman et al, (1987), raising it by soil liming leads to significant uptake reduction. The recommended levels are for Cd 0.05-0.2 ppm and $\mathrm{Pb} 0.5-10 \mathrm{ppm}$, while the toxic levels of these elements are 5-30 ppm and 10-100 ppm, respectively (Davis et al., 1978). The concentration of $\mathrm{Cd}, \mathrm{Pb}, \mathrm{Cu}$ and $\mathrm{Zn}$ in the edible parts of the test plants treated by sewage sludge (Tables 4 and 5) were generally near the normal range and less than the toxic levels as mentioned before. 


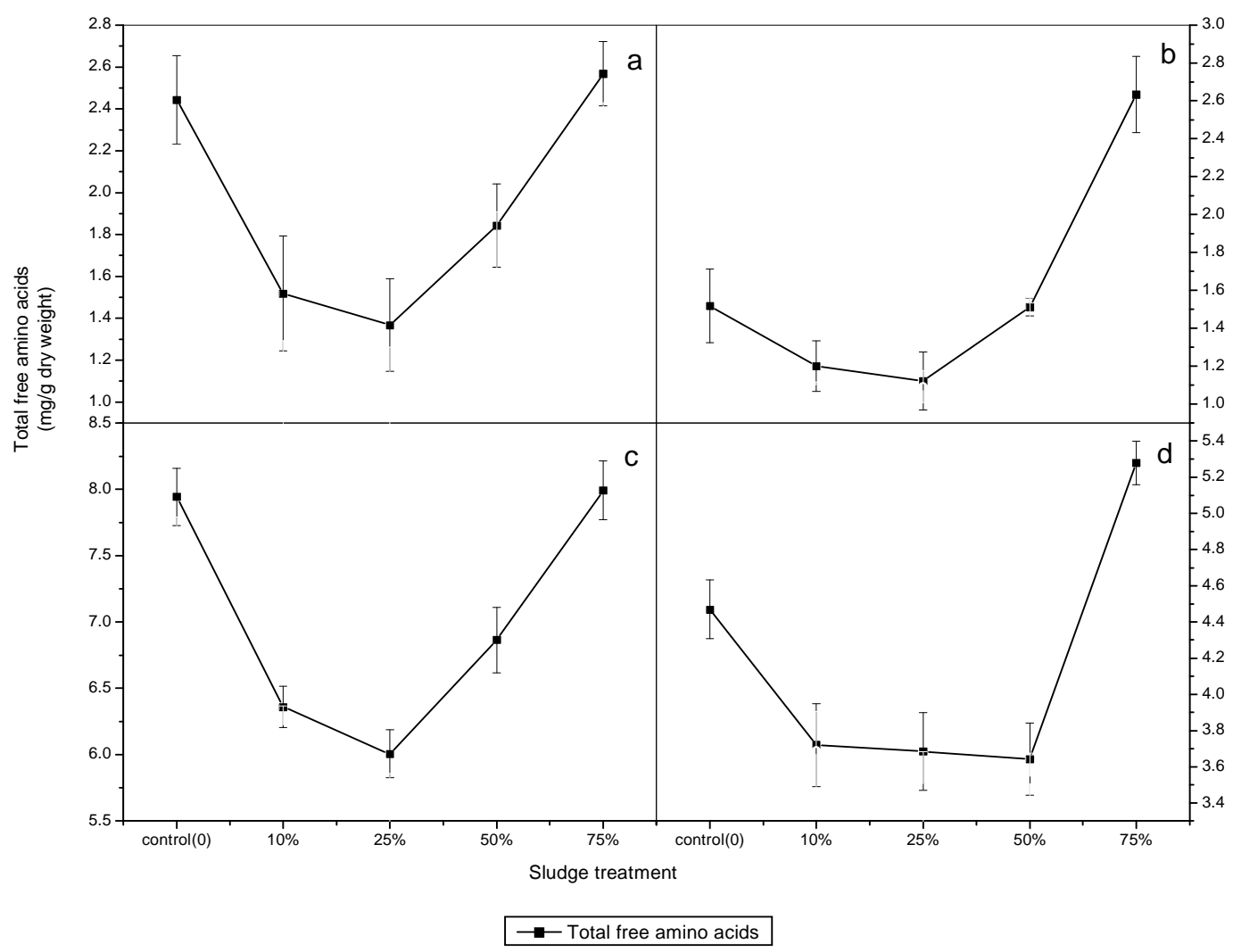

Figure 5 - Effect of addition of various ratios of sewage sludge to desert soil on which wheat and jews mallow were growing on their total free amino acids content of: a) shoot of wheat plants; b) root of wheat plants; c) shoot of jews mallow plants; d) root of jews mallow plants. Each data point is a mean of three replicates and error bar on each data point equal \pm Standard Deviation (SD) from that mean.

Table 4 - Effect of addition of various ratios of sewage sludge to desert soil on which wheat was growing on it's shoot, root and grains heavy metals content. Each value is a mean of three replicates \pm Standard Deviation (SD) from that mean.

\begin{tabular}{|c|c|c|c|c|c|}
\hline \multirow{2}{*}{ Plant part } & \multirow{2}{*}{ Treatment } & Cd & $\mathbf{C u}$ & $\mathbf{P b}$ & $\mathbf{Z n}$ \\
\hline & & \multicolumn{4}{|c|}{$\mathrm{mg} / \mathrm{kg}$} \\
\hline \multirow{5}{*}{ Shoot } & Control (0\% SS) & $0.200 \pm 0.100$ & $4.367 \pm 1.097$ & $5.633 \pm 0.208$ & $19.607 \pm 0.140$ \\
\hline & $10 \% \mathrm{SS}$ & $0.267 \pm 0.115$ & $4.200 \pm 0.721$ & $5.753 \pm 0.234$ & $20.953 \pm 0.530$ \\
\hline & $25 \% \mathrm{SS}$ & $0.267 \pm 0.058$ & $5.500 \pm 0.700$ & $5.873 \pm 0.130$ & $20.933 \pm 0.310$ \\
\hline & $50 \% \mathrm{SS}$ & $0.333 \pm 0.058$ & $6.933 \pm 2.572$ & $6.033 \pm 0.252$ & $22.267 \pm 0.878$ \\
\hline & $75 \% \mathrm{SS}$ & $0.367 \pm 0.058$ & $9.233 \pm 2.173$ & $6.493 \pm 0.332$ & $23.3 \pm 0.250$ \\
\hline \multirow{5}{*}{ Root } & Control $(0 \% \mathrm{SS})$ & $0.233 \pm 0.115$ & $5.467 \pm 0.551$ & $5.627 \pm 0.230$ & $20.233 \pm 0.704$ \\
\hline & $10 \% \mathrm{SS}$ & $0.267 \pm 0.115$ & $9.333 \pm 0.252$ & $6.127 \pm 0.333$ & $21.020 \pm 0.733$ \\
\hline & $25 \% \mathrm{SS}$ & $0.700 \pm 0.100$ & $13.533 \pm 2.250$ & $6.427 \pm 0.050$ & $21.987 \pm 0.258$ \\
\hline & $50 \% \mathrm{SS}$ & $1.000 \pm 0.100$ & $15.167 \pm 2.401$ & $6.747 \pm 0.090$ & $21.827 \pm 0.831$ \\
\hline & $75 \% \mathrm{SS}$ & $1.900 \pm 0.608$ & $16.567 \pm 1.401$ & $7.687 \pm 0.110$ & $22.913 \pm 0.613$ \\
\hline \multirow{5}{*}{ Grains } & Control (0\% SS) & $0.050 \pm 0.000$ & $5.450 \pm 0.328$ & $4.290 \pm 0.117$ & $14.424 \pm 0.125$ \\
\hline & $10 \% \mathrm{SS}$ & $0.067 \pm 0.029$ & $6.476 \pm 0.437$ & $4.319 \pm 0.076$ & $15.844 \pm 0.714$ \\
\hline & $25 \% \mathrm{SS}$ & $0.100 \pm 0.050$ & $8.450 \pm 1.106$ & $4.547 \pm 0.241$ & $16.092 \pm 0.504$ \\
\hline & $50 \% \mathrm{SS}$ & $0.150 \pm 0.050$ & $8.483 \pm 0.902$ & $4.543 \pm 0.095$ & $16.102 \pm 0.341$ \\
\hline & $75 \% \mathrm{SS}$ & $0.150 \pm 0.050$ & $8.333 \pm 0.775$ & $4.800 \pm 0.087$ & $16.202 \pm 0.368$ \\
\hline
\end{tabular}


Table 5 - Effect of addition of various ratios of sewage sludge to desert soil on which Jews mallow was growing on it's shoot and root heavy metals content. Each value is a mean of three replicates \pm Standard Deviation (SD) from that mean.

\begin{tabular}{cccccc}
\hline \multirow{2}{*}{ Plant part } & Treatment & $\mathbf{C d}$ & $\mathbf{C u}$ & \multicolumn{2}{c}{$\mathbf{m g} / \mathbf{k g}$} \\
& Control (0\% SS) & $0.433 \pm 0.153$ & $7.333 \pm 1.358$ & $5.800 \pm 0.200$ & $20.573 \pm 0.331$ \\
& $10 \%$ SS & $0.600 \pm 0.100$ & $7.767 \pm 2.139$ & $6.180 \pm 0.109$ & $20.913 \pm 0.533$ \\
Shoot & $25 \%$ SS & $1.167 \pm 0.153$ & $10.300 \pm 1.217$ & $6.393 \pm 0.122$ & $23.007 \pm 0.356$ \\
& $50 \%$ SS & $1.500 \pm 0.361$ & $10.033 \pm 1.305$ & $6.573 \pm 0.050$ & $24.107 \pm 0.660$ \\
& $75 \%$ SS & $1.667 \pm 0.257$ & $13.767 \pm 3.755$ & $6.853 \pm 0.343$ & $24.507 \pm 0.349$ \\
\hline \multirow{5}{*}{ Root } & Control (0\% SS) & $0.733 \pm 0.153$ & $9.500 \pm 2.689$ & $6.253 \pm 0.232$ & $23.247 \pm 0.190$ \\
& $10 \%$ SS & $1.233 \pm 0.153$ & $12.600 \pm 1.637$ & $6.320 \pm 0.156$ & $23.820 \pm 0.156$ \\
& 25\% SS & $1.633 \pm 0.252$ & $15.533 \pm 1.858$ & $6.886 \pm 0.121$ & $24.227 \pm 0.299$ \\
& $50 \%$ SS & $2.133 \pm 0.306$ & $17.333 \pm 1.150$ & $7.380 \pm 0.322$ & $24.713 \pm 0.151$ \\
& $75 \%$ SS & $2.667 \pm 0.208$ & $18.100 \pm 1.153$ & $7.700 \pm 0.050$ & $25.533 \pm 0.367$ \\
\hline
\end{tabular}

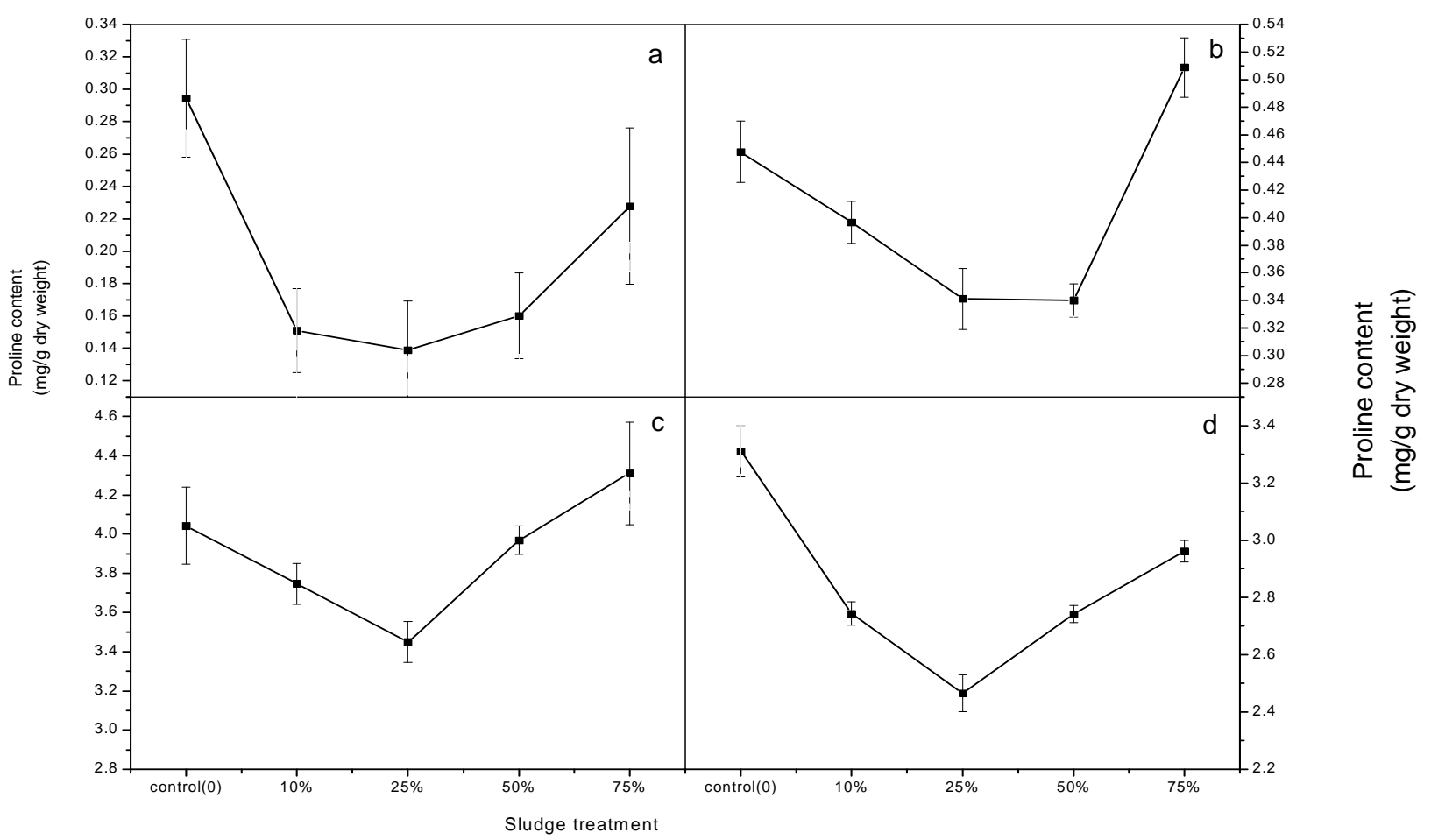

Figure 6 - Effect of addition of various ratios of sewage sludge to desert soil on which wheat and jews mallow were growing on their proline content of: a) shoot of wheat plants; b) root of wheat plants; c) shoot of jews mallow plants; d) root of jews mallow plants. Each data point is a mean of three replicates and error bar on each data point equal \pm Standard Deviation (SD) from that mean.

\section{CONCLUSIONS}

The amendment of desert soil with sewage sludge showed improvement in the physical and chemical properties of the soil as soil texture, increases in water holding capacity and organic matter contents, and lower $\mathrm{pH}$ value in resulting mixtures.
The contents of NPK elements gradually increased as the ratio of sewage sludge increased in the mixtures. Also, there was an improvement in physiological performance of these plants, expressed as general growth, content of photosynthetic pigments, proteins and carbohydrates. There was no accumulation of 
amino acids and proline in these tissues. The accumulation of metals was generally higher in the root than that in the shoot system.

\section{REFERENCES}

Alia; Mohanty, P. and Matysik, J. (2001), Effect of proline on the production of singlet oxygen. Amino Acids, 21, 195-200.

Antolín, M. C.; Pascual, I.; García, C.; Polo, A. and Sánchez-Díaz, M. (2005), Growth, yield and solute content of barley in soils treated with sewage sludge under semiarid Mediterranean conditions. Field Crops Research, 94, 224-237.

Aoshima, K.; Fan, J.; Cai, Y.; Katoh, T.; Teranishi, H. and Kasuya, M. (2003), Assessment of bone metabolism in cadmium-induced renal tubular dysfunction by measurements of biochemical markers. Toxic Lett., 136, 183-192.

Barzegar, A. R.; Yousefi, A. and Daryashenas, A. (2002), The effect of addition of different amounts and types of organic materials on soil physical properties and yield of wheat. Plant Soil, 247, 295301.

Bates, L. S.; Waldern, R. P. and Teare, I. D. (1973), Rapid Determination of free proline for water stress studies. Plant Soil, 39, 205-207.

Birley, M. H. and Lock, K. (2001), A review of the health impacts of perurban Natural resource development. International Centre for Health Impact Assessment, Liverpool School of Tropical Medicine, Pembrooke Place, Liverpool, England, Draft.

Chaney, R. L.; Hundermann P. T.; Palmer, W. T.; Small R. J.; White, M. C. and Decker, A. M. (1978), Plant accumulation of heavy metals and phytotoxicity resulting from utilization of sewage sludge and sludge compost on crop land. In: Proc. Natl. Conf. Composting minicipal residues and sludge, silver spring, MD. August 1977. PP 86-97. Information transfer, Inc., Rockville, MD.

Chaney R. L. and Ryan, J. A. (1993), Heavy metals and toxic organic pollutants in MSW-compost: Research results on phytoavailability, fate, etc. In Hotlink H.A.J. et al. (Eds) Science and Engineering of Composting- Design, Environmental, Microbiological and Utilization Aspects. The Ohio State University, Columbus, $\mathrm{OH}$.

Cottenie, A.; Verloo, M.; Kiekens, L.; Velghe, G. and Camerlynck, R. (1982), "Chemical analysis of plants and soils". Lab. Anal. and agrochem. State Univ. Gent. Belgium, Chapters 2, 3, pp. 14-54.

Christie, P.; Easson, D. L.; Picton, J. R. and Love, S. C. P. (2001), Agronomic value of alkaline-stabilized sewage biosolids for spring barley. Agron. J. 93, 144151.
Christodoulos, N. S. and Margarita, N. S. (1996), Growth of corn (Zea mays) and sunflower (Helianthus annuus) plants is affected by water and sludge from a sewage treatment plant. Bull. Environ. Contam. Toxicol. 57, 300-306.

Davis, R. D.; Beckett and P. H. Wollan, E. (1978), Critical levels of twenty potentially toxic elements in young spring barley. Plant and Soil, 49, 395.

Davis, R.D. (1987): Use of sewage sludge on land in the United Kingdom. Wat. Sci. Technol. 19 (1), 1-8.

Dewis, J. and Freites, F. (1970): Physical and chemical methods of soil and water analysis. FAO, Rome, Soil Bulletin, No. 10.

Faheed, F. A. (2005), Effect of lead stress on the growth and metabolism of Eruca Sativa M. seedlings. Acta Agronomica, 53, 319-327.

Fales, F. W. (1951), The assimilation and degradation of Carbohydrates by yeast cells. J, Biol. Chem., 193: 113.

Garcia-Gil; J. C., Plaza, C.; Senesi, N.; Brunetti, G. and Polo, A. (2004), Effects of sewage sludge amendment of humic acids and microbiological properties of a semiarid Mediterranean soil. Biol. Fertil. Soils, 39, 320-328.

Hao, X., Chang, C., 2003: Does long-term heavy cattle manure applications increase salinity of a clay loam soil in semi-arid southern Alberta? Agric. Ecosyst. Environ. 94, 89-103.

Hare, P. D. and Cress, W. A. (1997), Metabolism implications of stress-induced proline accumulation in plants. Plant Growth Regul., 21, 79-102.

Heckman, J. R.; Angle J. S. and Chaney, R. L. (1987), Residual effects of sewage sludge on soybean: II. Accumulation of soil and symbiotically fixed nitrogen. J. Environ. Qual., 16 (2), 118-124.

Hoagland, D. R. and Arnon, D. I. (1950), The water culture method plants without soil. California Agric. Exp. Stat. Univ. Calif., Berkeley Circ., 374.

Jackson, M. L. (1958), "Soil Chemical Analysis". Prentice-Hall Inc., U. S.A.

Jackson, M. L. (1967), "Soil Chemical Analysis". Prentice-Hall India Part. Ltd., New Delhi, India.

Leskó K.; Stefanovits-Bányai, É and Simon-Sarkadi L. (2002), Effect of magnesium on free amino acid and polyamine content in wheat seedling exposed to cadmium stress. Acta Biologica Szegediensis, 46 (34), 109-111.

Lester, J. N., Sterritt R. M. and Kirk P. W. W. (1983): Significance and behavior of heavy metals in waste water treatment proccessses. $\Pi$ : Sludge treatment and disposal. Sci. Total Envir., 30: 45-83.

Lindsay, W. L. and Norvell, W. A. (1978), Development of DTPA soil test for zinc, iron, manganese and copper. Soil Sci. Soc. Amer. J., 42, 421. 
Lowery, O. H.; Rosebrough, N. J.; Farr, A. L. and Ranall, R. J. (1951), protein measurement with the folin phenol Reagent. J. Biol. Chem., 193, 291-297.

Mazen, A. M. A. (1995), assessment of heavy metal accumulation and performance of some physiological parameters in Zea mays and Vicia faba L grown on soil amended by sewage sludge resulting from sewage water treatment in the State of Qatar. Qatar Univ. Sci. J., 15(2), 353-359.

Mazen, A. M. A. (2003), Heavy metal accumulation and physiological consequences in selected food plants grown on sewage sludge amended soils. Arab Gulf Journal of Scientific Research, 21(3), PP 140147.

McGrath, S. P., Zhao, F. J., Dunham, S. J., Crosland, A.R., Coleman, K., 2000: Long-term changes in extractability and bioavailability of zinc and cadmium after sludge application. J. Environ. Qual. 29, 875883.

Mehta, S. K. and Gaur, J. P. (1999), Heavy-metalinduced proline accumulation and its role in ameliorating metal toxicity in Chlorella vulgaris. New Phytol., 143, 253-259.

Metzner, H.; Rau, H. and Senger, H. (1965), Untersuchunger Zur Synchronisierbarkeit einzelnerpigment-Mangel Mutanten Von Chlorella. Planta, 65, 186-194.

Moore, S. and Stein, W. (1948), Photometric ninhydrin method for use in the chromatography of amino acids. Journal of biological chemistry, 187, 367-388.

Narwal, R. P. and Singh, M. (1993), Effect of cadmium and zinc application on quality of maize. Indian $J$. Plant Physiol., 34, 170-173.

Olsen, S. R. and Sommers, L. E. (1982), Phosphorus: phosphorus soluble in sodium bicarbonate. In: A.L. Page et al. (Ed.) Methods of Soil Analysis. Part2. $2^{\text {nd }}$ ed. Agron. Monogr. G. ASA and SSSA, Madison, WI. PP. 421-422.

Rai, V.; Khatoon, S.; Bisht, S. S. and Mehrotra, S. (2005), Effect of cadmium on growth, ultramorphology of leaf and secondary metabolites of Phyllanthus amarus Schum. and Thonn. Chemosphere, 61, 1644-1650.

Ranki, H.; Sopanen, T. and Voutilainen, R. (1990), Localization of carboxypeptidase-I in germinating barley grain. Plant Physiol., 93, 1449-1452.

Richards, L. A. (1954), Diagnosis and improvement of saline and alkaline soils. U.S.D.A. Handbook.

Saviozzi, A.; Biasci, A.; Riffaldi, F. and Levi-Minzi, R. (1999), Longterm effects of farmyard manure and sewage sludge on some soil biochemical characteristics. Biol. Fertil. Soils, 30, 100-106.

Schmidt, J. P. (1997), Understanding phytotoxicity threshold for trace element in land-applied sewage sludge. J. Environ. Qual., 26, 4-10.

Shah, K. and Dubey R. S. (1998a), Cadmium elevates level of protein, amino acids and alters the activity of proteolytic enzymes in germinating rice seeds. Acta Physiol. Plant, 20, 189-196.

Shah, K. and Dubey R. S. (1998b), Effect of cadmium on proline accumulation and ribonuclease activity in rice seedlings: role of proline as a possible enzyme protectant. Biol. Plant, 40, 121-130.

Siripornadulsil S.; Traina S.; Verma, D. P. S. and Sayre R. T. (2002), Molecular mechanisms of prolinemediated tolerance to toxic heavy metals in transgenic microalgae. Plant Cell, 14, 2837-2847.

Smirnoff, N. and Cumbes, Q. J. (1989), Hydroxyl radical scavenging activity of compatible solutes. Phytochemistry, 28, 1057-1060.

Speir, T. W.; Van Schaik, A. P.; Lloyd-Jones, A. R. and Kettles, H. A. (2003), Temporal response of soil biochemical properties in a pastoral soil after cultivation following high application rates of undigested sewage sludge. Biol. Fertil. Soils, 38, 37385.

Taylor, C. B. (1996), Proline and water deficit: Ups, downs, ins and outs. Plant cell, 8, 1221-1224.

Tietjen, C. (1975), Principal problems of the use of city wastes for crop production and soil conservation. FAO Soil Bulletin, 27, 221.

U. S. Environmental protection Agency (1993), 40 CRF part 257 et al., standards for the Use or Disposal of Sewage Sludge; Final Rules. Fed. Reg., 58 (32), 9284.

Verma, D. P. S. (1999), Osmotic stress tolerance in plants: Role of proline and sulfur metabolisms. In Molecular Responses to Cold, Drought, Heat and Salt Stress in Higher Plants, K. Shinozaki and K. Yamaguchi-Shinozaki, eds (Austin, TX: R.G. Landers), pp. 153-168.

Veeresh, H.; Tripathy, S.; Chaudhuri, D.; Ghosh, B. C.; Hart, B. R. and Powell, M. A. (2003), Changes in physical and chemical properties of three soil types in India as a result of amendment with fly ash and sewage sludge. Environ. Geol., 43, 513-520.

William, A. (1989): The effect of cell cycle regulators on protein profiles in cultured root meristems of Pesium sativum. Enviro. Exp. Bot. 29(3): 317-322.

Yancey, P. H.; Clark, M. E.; Hand, S. C.; Bowlus, R. D. and Somero, G. N. (1982), Living with water stress: evolution of osmolyte systems. Science, 217, 12121222.

Zasoski, R. J.; Cole, D. W. and Bledsoe, C. S. (1983), Municipal sewage sludge use in forests of the Pacific Northwest, USA: Growth response. Water Management and Res., 1 (2), 103.

Received: March 05, 2008; Revised: February 13, 2009; Accepted: April 15, 2009. 